\title{
Interior Photograph Experiment of The House Tour Hotel Bandung
}

\author{
Sandy Dwi Putra ${ }^{1}$, Kankan Kasmana ${ }^{2}$ \\ ${ }^{1,2}$ Program Studi Magister Desain Fakultas Pascasarjana Universitas Komputer Indonesia \\ Jl. Dago (Ir. H. Djuanda) No. 160-162 Bandung 40132 \\ email : sandydwiputra25@gmail.com
}

\begin{abstract}
The rapid advancement of information and communication technology influences the growth of creative industries such as firms in the fields of architecture, real estate and interior. The firm uses the advantages of information and communication technology, namely the internet and social media to conduct marketing. The use of social media as a marketing strategy of real estate and interior firms today is increasingly used as a promotional medium. The use of photos especially for interior promotion requires good photography techniques, has the power to stir consumer perception of interior services. This research aims to conduct photography experiments on the interior of The House Tour Hotel, designed by an architecture firm called Be Good Design Architect, this experiment was conducted to find out the techniques of photography in photographing the interi or. The method used is photography experimentation using photography techniques based on literature and photographic methods from interviews with professional photographer Mario Wibowo. The result of this experiment is interior photo taken from the bedroom room of The House Tour Hotel.
\end{abstract}

Keywords: Interior; Mario Wibowo; Photography; Promotion; The House Tour Hotel 


\title{
Interior Photograph Experiment of The House Tour Hotel Bandung
}

\author{
Sandy Dwi Putra \& Kankan Kasmana
}

\section{INTRODUCTION}

The rapid development of information and communication technology, triggering economic growth and competition among businessman. Property industry players such as firms in architecture, real estate and interior firms continue to innovate in presenting interesting digital information content to be disseminated through web pages and social media. Suharfin (2018) stated, the development of technology is inevitable in life, because technological advances are in line with the development of science. Today in the digital information age, human activity begins to shift to cyberspace, with internet technology, information is very quickly spreading and easy to obtain.

People of the information technology era get information and communicate mostly using technological devices. According to Ayun (2015), currently there is a cultural shift, the younger generation is doing all their personal activities through the internet and their social media accounts. The phenomenon is utilized by businesses as an opportunity to develop their company through promotions to attract a larger audience. Through the Marketing Communication division every property and interior firm conducts digital promotional efforts. The increasing use of social media by the public is used as an opportunity to promote through social media, such as Facebook, Instagram, Twiter and others. Firma Be Good Design Architect as an architect firm covering architects, property and interiors, utilizes social media in conducting promotions.

The House Tour Hotel is a client of the firm Be Good Design Architect. For promotional needs through social media, the firm Be Good Design Architect requires taking interior photos of The House Tour Hotel as a result of the work for the promotion. Riska Yunita (Personal communication, May 2020) said "The design of The House Tour Hotel is the firm Be Good Design Architect, to cooperate in the interior shooting project The House Tour Hotel needs a photographer who focuses on the field of architectural and interior photography expertise, before publishing the hotel to the public, the marketing party needs photographs that have the power to stir consumer perception". 


\section{Interior Photograph Experiment of The House Tour Hotel Bandung}

Sandy Dwi Putra \& Kankan Kasmana

According to Harsanto (2020), a real-life photo display can facilitate persuasion for the person viewing it. The image quality in a photograph is determined by how a photographer can capture an image with the right perspective, technique and composition. According to Zakia and Page (2011), composition is the ability to pay attention and see the shapes and shapes of objects, textures, lines, masses, and the like, as well as their relationships with each other. Thus the imagery will be perfectly formed, have good photo quality and have persuasive nature. Related to this, in the process of shooting the interior of The House Tour Hotel conducted photographic experiments. This research was conducted through interior photography experiments, aimed at finding out photographic compositions that could make the audience more comfortable.

\section{METHOD}

The research method used is experiments, using room photography methods obtained from an interview with professional photographer Mario Wibowo in January 2020. The method consists of several stages, namely photography preparation, location observation, angle-of-view, composition determination, equipment preparation, lighting, exposure, and figure. The method in the composition stage uses the rule of third photography method. The rule of third is a common composition technique that divides a photo frame into the same grid, $3 \times 3$ with two horizontal lines and two vertical lines intersecting at four points. The Third Rule places the subject on the left or right third of the frame, creating a balanced and visually appealing composition (What Is the Rule of Thirds in Photography? How to Practice the Rule of Thirds and Photography Tips, 2020).

In data collection, researchers perform several stages:

1. Collect books, articles, journals and scientific research on photography theories and design science perspectives. Some quoted from print and internet related media sources are also a reference.

2. Conduct in-depth interviews with professional photographers who focus on interior photography and record all information on research topics. The interview process is conducted 


\title{
Interior Photograph Experiment of The House Tour Hotel Bandung
}

\author{
Sandy Dwi Putra \& Kankan Kasmana
}

face-to-face or indirectly, can be by phone, e-mail, and social media. The goal is to get as much information as possible about the object being studied.

3. Solving problems in the field, by conducting experiments directly to The House Tour Hotel to produce persuasive, informative and professional interior photos, based on photography techniques.

\section{RESULTS AND DISCUSSION}

\section{Interior Photography}

Interior photography is the process of translating a work of architecture - an interior that has shape, concept and space into the form of a 2 (two) dimensional image. Interior photography is a commercial stream of photography tasked with documenting interior spaces in a representative, informative and communicative manner. Interior photography is a form of recording of a building or room, in interior photography a photographer needs to conduct rigorous training, trials and use a variety of techniques (Saint-D, 2019). According to Narcissist (2017), mastering basic lighting techniques is paramount in interior photography, the correct use of lighting will result in sharper and more realistic photographs.

Shooting with the correct lighting is the main technique in any genre of photography and it can train a photographer's sensitivity in shooting different shapes and different types of objects. According to the site Soocaphoto.com if the indoor light is less bright, it is necessary to add light from external lights and the light is adjusted to the needs of the room. Interior photography has a different level of complexity than every other photography genre, e.g. from field cases, equipment types, to photography techniques used. The lenses used in interior photography are PC-E or Tilt Shift lenses. This lens can adjust the tilt of the building, so that the resulting photo is not distorted. 


\section{Interior Photograph Experiment of The House Tour Hotel Bandung}

\section{Sandy Dwi Putra \& Kankan Kasmana}

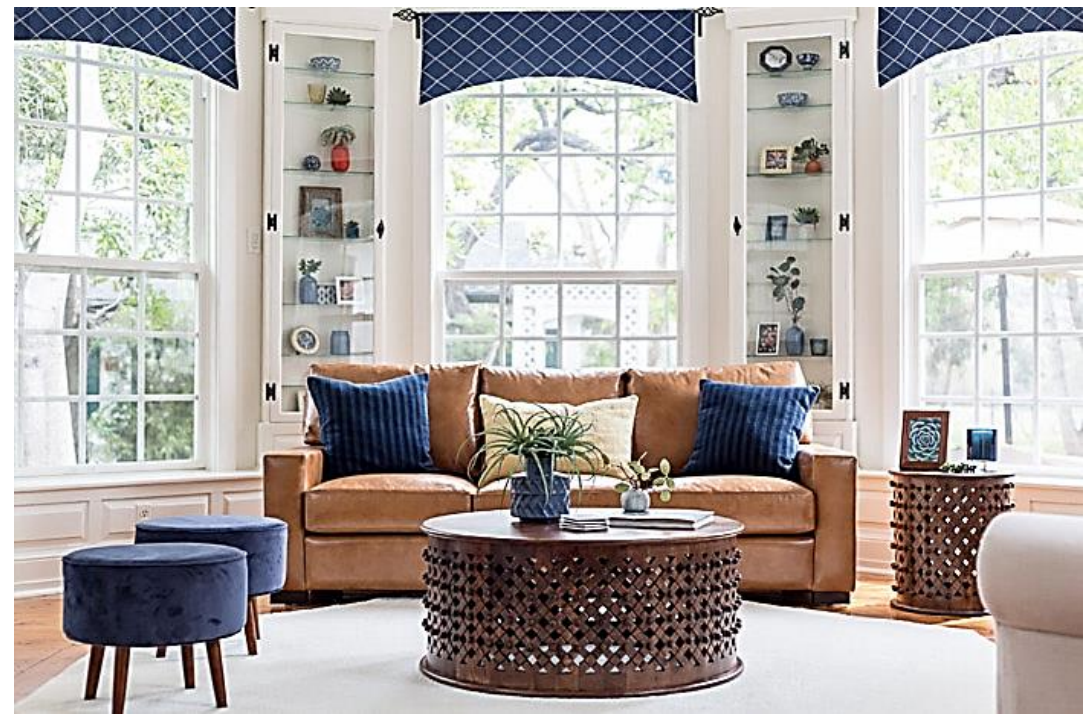

Figure 1 Photo of Interior

Source: https://expertphotography.com/wp-content/uploads/2020/05/Interior-photographynatural-light-living-room-1.jpg Accessed on September 05, 2020

\section{Preparing for Photography}

Preparation before shooting is the key to success, it is necessary to research the shooting location and find out about the history of the building as an inspiration for the photo. Before starting to shoot an interior space, the photographer needs to survey the room to be photographed, so that the photographer will get an idea of the shooting location, the problems encountered and make it easier for a photographer to determine what equipment $\mathrm{M}$ is using (2016). According to Siskin, (2012) interior photography requires a good sensitivity to feel the space, including details, colors, light, textures, and decorations should be considered.

\section{A. Equipment}

The right photography equipment can maximize the results of photos, especially when it comes to architectural and interior photography, requiring a wide angle (11 Techniques To Produce Cool And Amazing Architectural Photography. Foto.co.id, 2020). Camera equipment consists of several types, such as: Lens, Body Camera, Trigger, External Flash and Tripod. Each of 
these equipments plays an important role in every interior space shooting process. Moreover, if supported by premium quality equipment, it will be easier to produce photos that are sharper, brighter and have professional quality.

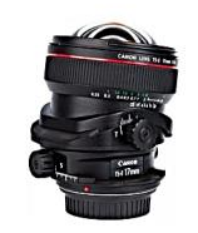

Lensa Tilt Shift $17 \mathrm{~mm}$

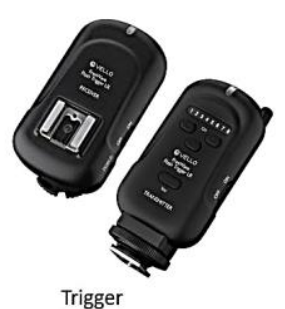

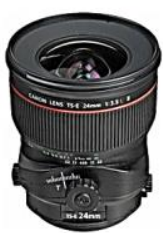

Lensa Tilt Shift $24 \mathrm{~mm}$

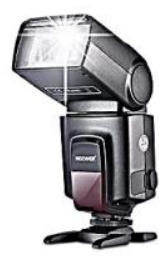

Flash External

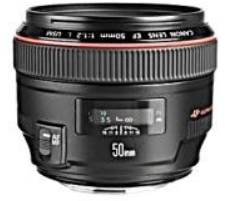

Lensa Fixed $50 \mathrm{~mm}$

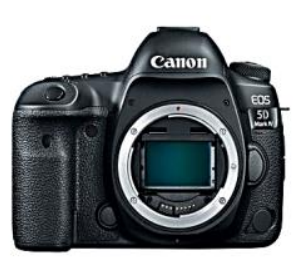

Kamera DSLR

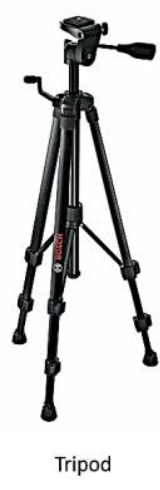

Figure 2. Photography Equipment

Source: https://pondoklensa.com/sewa/product/canon-ts-e-17mm-f4-1-tilt-shift-lens.jpg Accessed on September 05, 2020

\section{B. Angle}

In shooting angles in interior photography, there needs to be a harmonious unity of supporting elements to produce the right angle and feel good to look at (20 Photo Composition Techniques for Improving Photography Skills, K-Shot, 2017). Before determining the angle of capture, a photographer needs to look at the composition of space and the area of space. For composition and perspective to look perfect in one photo frame. According to Narcissist (2017) perspective in interior photography is not just about composition. The harmony of many components such as symmetry, rhythm, contrast, and light will make each photo captivate the audience. According to the website keeindonesia.com to give the impression of a photo object that has a dimension of space, it is necessary to make use of the composition at the shooting angle. 


\section{Interior Photograph Experiment of The House Tour Hotel Bandung}

Sandy Dwi Putra \& Kankan Kasmana

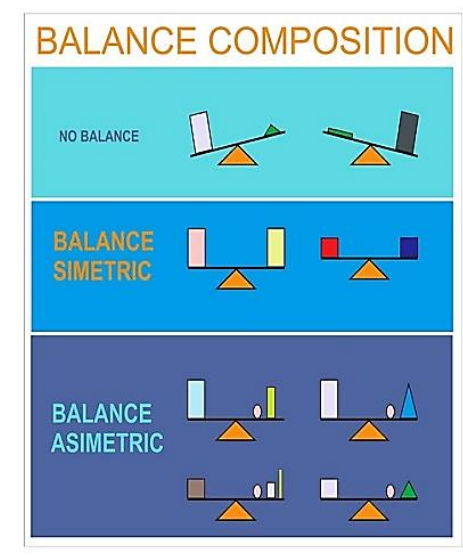

Figure 3. Photography Composition of Interior

Source: https://d25tv1xepz39hi.cloudfront.net/2017-10-09/files/illustration.jpg Accessed on September 05, 2020

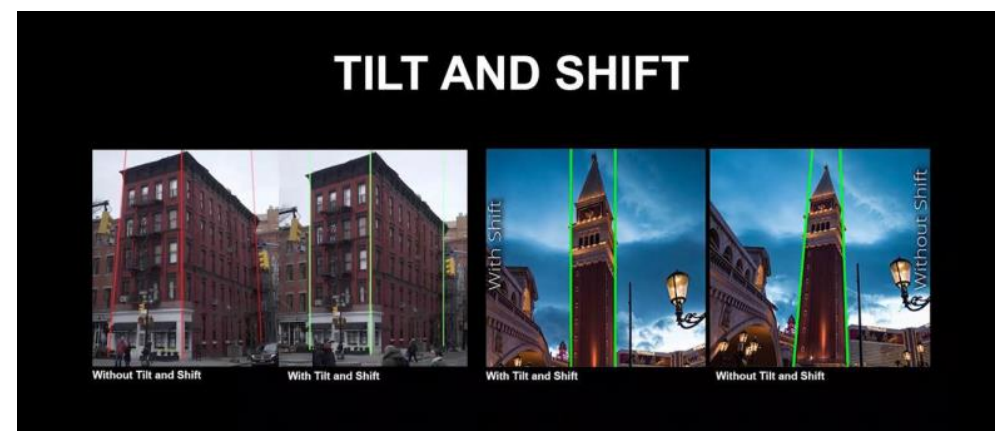

Figure 4. Distorted Photo Perspective

Source: https://petapixel.com/assets/uploads/2015/04/tiltshiftheader.jpg Accessed on September 05, 2020

\section{Lighting}

Lighting is the most important thing when photographing the interior, according to Wahyono (2016), lighting is an important aspect to produce a perfect image, therefore the intensity of light used must be balanced with the object being photographed. The best light source is natural light, according to Andina (2020), naturally available light can be used to photograph the interior.

Copyright (c) 2020 Sandy Dwi Putra, Kankan Kasmana 


\section{Interior Photograph Experiment of The House Tour Hotel Bandung}

\section{Sandy Dwi Putra \& Kankan Kasmana}

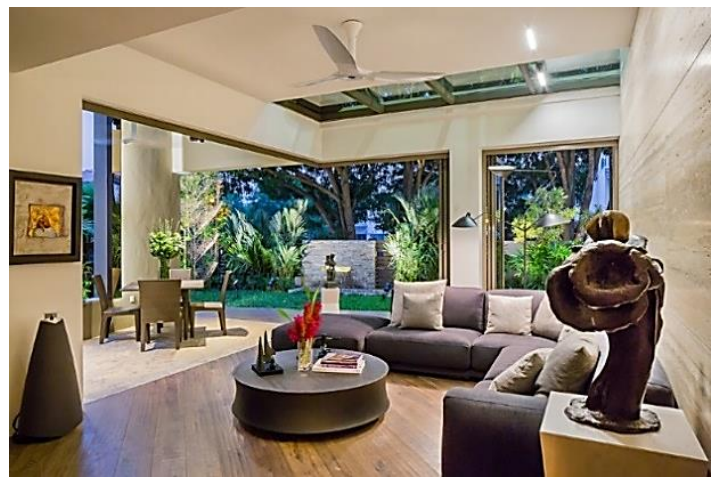

Figure 5. Interior Photo Shooted on Sunset

Source: https://d25tv1xepz39hi.cloudfront.net/2016-06-04/files/Interior_Spaces_image1.jpg Accessed on September 05, 2020

D. Exposure

According to M (2016), when shooting commercial spaces, it is important to capture all the interior elements to capture the attention of customers. Like fine details, the clear texture or contrast of the furniture is the part that determines the atmosphere of the room. Therefore, when shooting interior it is recommended to use higher apertures (such as $\mathrm{f} / 8-\mathrm{f} / 22$ ), a low ISO and longer exposure to ensure each element looks sharp in the image.

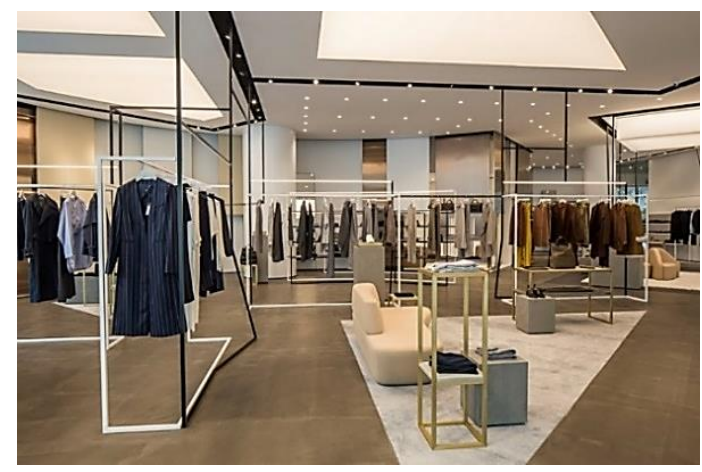

Figure 6. Photograph of Interior in Detail

Source: https://www.mattclaytonphotography.co.uk/wpcontent/uploads/2019/01/MClayton_1811-6-BTL-WhiteLodge1058_D-Lres.jpg Accessed on September 05, 2020 


\section{Interior Photograph Experiment of The House Tour Hotel Bandung}

Sandy Dwi Putra \& Kankan Kasmana

\section{E. Human Figures}

According to Hyun (2016), the use of human figures in photo representations can increase the additional role that concerns the richer aspects of a building or space. where human figures can convey architectural properties and realize how architecture can be shaped to accommodate the human experience.

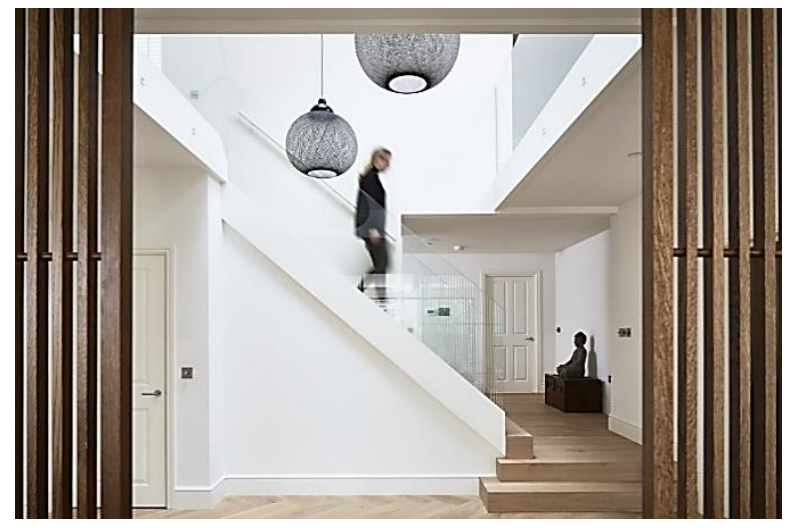

Figure 7. Use of Human Figure on Photo

Source: https://www.mattclaytonphotography.co.uk/wpcontent/uploads/2019/01/MClayton_1811-6-BTL-WhiteLodge1058__D-Lres.jpg Accessed on September 05, 2020

\section{The House Tour Hotel}

The House Tour Hotel is a 2 (two) star rated class hotel with a boutique hotel type, according to Wright (2011), boutique hotel is different from commercial hotel, boutique hotel only attaches importance to quality service and has a design that will never be duplicated. Boutique hotels offer originality in terms of structural features, architectural design, furniture, décor and materials used, superior operating standards and high-quality personalized services with experience or trained employees (Gökdeniz, 2018). According to the source of the interview through Google Form, Maja Group's source, Brand Manager Riska Yunita (Personal Communique, May 2020) said that The House Tour Hotel was designed by an agency 


\title{
Interior Photograph Experiment of The House Tour Hotel Bandung
}

\author{
Sandy Dwi Putra \& Kankan Kasmana
}

consultant named Be Good Design Architect, the construction of the hotel was completed and started to operate in 2018.

The House Tour Hotel is located on Jl. Panumbang Jaya No.5 Bandung, located in a very strategic area that is in the Ciumbuleuit area. The area is within close proximity of attractions such as Rabbit Town, Cihampelas Walk and Punclut. To get to The House Tour Hotel can use private vehicles and public transportation such as: angkot, taxis, and other vehicles based online. The House Tour Hotel is one of the hotels of Maja Group, a company engaged in hospitality, restaurant and function hall. According to Maja Group's website, The House Tour Hotel carries the concept of new urban with a little touch of bohemian nature and tropical style, which gives the impression of a warm atmosphere and in harmony with the cool climate of Bandung. The purpose of the concept of new urban means a form of design that can promote environmentally friendly habits and blend with nature, with the concept of new urban is expected to provide correctness and comfort for every visitor to the hotel. For the exterior and interior façade of The House Tour Hotel is dominated by such colors; white, green, brown and orange, other colors also appear from the exposé colors of natural materials such as: brick and wood. According to hicoates site the color brings a sense of comfort in the room and gives a warm impression (Hicoates, 2020).

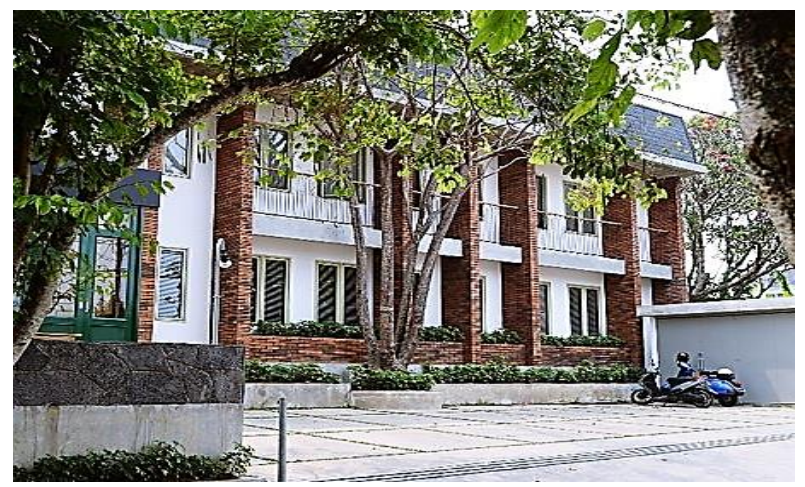

Figure 8. Exterior of The House Tour Hotel

Source: https://whatsnewindonesia.com/bandung/wp-content/uploads/sites/3/2018/11/hotelmain-building.jpg Accessed on September 05, 2020 


\section{Interior Photograph Experiment of The House Tour Hotel Bandung}

Sandy Dwi Putra \& Kankan Kasmana

The House Tour Hotel has 20 rooms divided into 4 different room types in size and style. Starting from medium size, large size, large size with balcony and extra large size with bathtub. The most preferred room by customers is the extra large room with bathtub, as this room provides a more visitor experience. According to a source from an interview through Google Form, Maja Goup's source, Brand Manager Riska Yunita (personal communication, May 2020) said The House Tour Hotel is intended for millennials who like something unique and different, the average age of visitors staying at The House Tour Hotel ranges from 25-40 years old. According to reviews on Google Review, visitors are very interested in visiting this hotel for photos (Google.com, 2020). Not infrequently this hotel is used as a pre-wedding photo location for couples who are getting married. In addition, for influencers (social media celebrities) the photo spots available in this hotel are very interesting, because it can be used to create product photo endorsement content such as: clothing, food or just a photo to collect materials uploaded on social media.

\section{Photography Experiments at The House Tour Hotel}

Mario Wibowo (personal communication, January 2020) said that before photographing the interior space must first conduct a survey / observation to the shooting location, it is necessary to know the problems and conditions in the field. After that the photographer searches for the angle of view and the perspective to be used at the time of shooting, all these stages are performed so that there are no interruptions during the shooting process. The next stage of preparing camera equipment, as for the camera equipment used during the interior shooting experiments of The House Tour Hotel, such as: Sony A6000, Lens 10-50mm f/3.5-5.6 and Tripod. Once all the camera equipment has been prepared, position the camera in the direction of the prepared angle of view and adjust the light triangle settings on the camera, adjust the lens aperture and set the tripod height. During the interior shooting experiment at The House Tour Hotel, a photographic visual study of the settings on the camera was conducted in the form of perspective, composition and light triangle settings (shutter speed, diaphragm and iso). 


\title{
Interior Photograph Experiment of The House Tour Hotel Bandung
}

\author{
Sandy Dwi Putra \& Kankan Kasmana
}

\section{Rule of Third}

According to Fajri, et al (2017), rule of third is one of the famous ways or tricks in the world of photography, this way is used to produce beautiful photos. In rule of third, the viewfinder and camera screen will be divided into 3 per 3 columns of the entire screen resulting in 9 columns in the screen, there are 4 midpoints that go through vertical and horizontal lines as (point of interest).

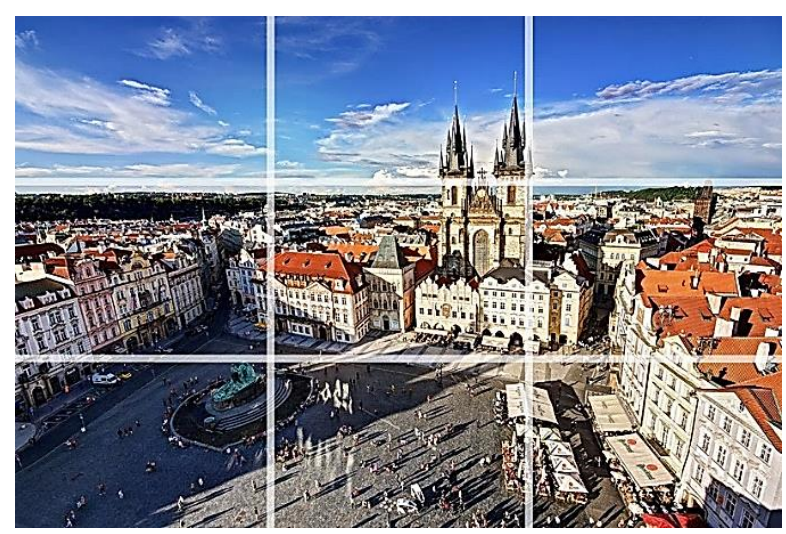

Figure 9. Rules of Third

Source: https://petapixel.com/assets/uploads/2016/09/rule-of-thirds-cityscape.jpg Accessed on September 05, 2020

During the interior shoot of The House Tour Hotel, the author applied photography techniques based on Mario Wibowo. In the composition of the rule of third point (point of interest) is focused on the lamp area. Here is a photo of the composition of the rule of third in the bedroom of The House Tour Hotel that the author has captured (see Figure 10).

In the bedroom shoot of The House Tour Hotel, for interior decoration nothing was shifted because the designer has arranged with balance and attractiveness, when shooting only need to adjust the position of the camera according to the composition of the rule of third. When shooting does not use artificial light from the camera, the reason is because the object is adjacent to the window that has a curtain that provides light bias, for light settings, using only the concept of a triangle of light found in the camera settings. 


\section{Interior Photograph Experiment of The House Tour Hotel Bandung}

Sandy Dwi Putra \& Kankan Kasmana

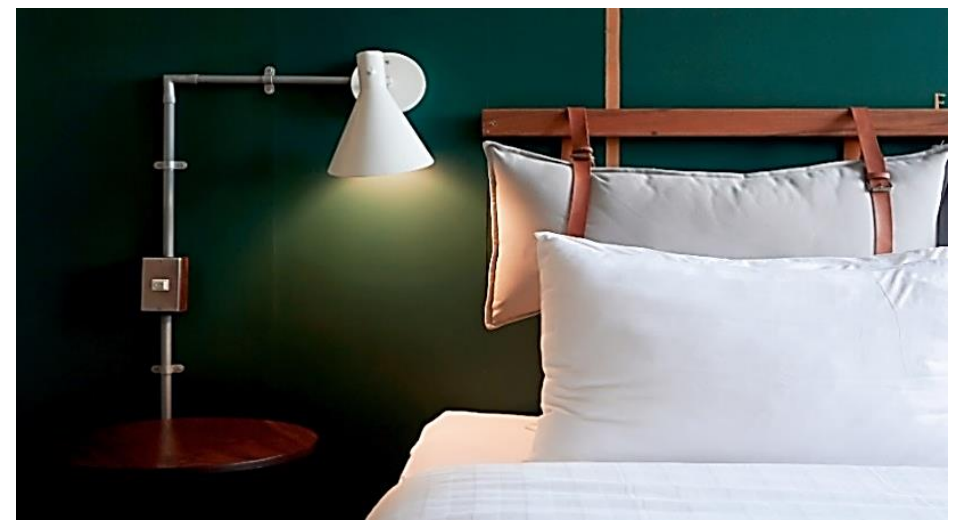

Figure 10. Rule of Third Composition (Bed Room, The House Tour Hotel)

Source: Author Document

Here are the light triangle settings on the camera that the author uses when photographing The House Tour Hotel's bedroom:

$\begin{array}{ll}\begin{array}{ll}\text { Camera } \\ \text { Camera maker }\end{array} & \text { SONY } \\ \text { Camera model } & \text { ILCE-6000 } \\ \text { F-stop } & \mathrm{f} / 6.3 \\ \text { Exposure time } & 1 / 20 \mathrm{sec} . \\ \text { ISO speed } & \text { ISO-100 } \\ \text { Exposure bias } & 0 \mathrm{step} \\ \text { Focal length } & 30 \mathrm{~mm} \\ \text { Max aperture } & 4 \\ \text { Metering mode } & \text { Spot } \\ \text { Subject distance } & \\ \text { Flash mode } & \text { No flash, compulsory }\end{array}$

Figure 11. Camera Adjustment on Rule of Third Commposition (Bed Room, The House Tour) Source: Author Document

Here is an explanation and usefulness of the camera settings used when photographing the bedroom of The House Tour Hotel according to Mario Wibowo (personal communication, January 2020). 


\title{
Interior Photograph Experiment of The House Tour Hotel Bandung
}

\author{
Sandy Dwi Putra \& Kankan Kasmana
}

a) Aperture: is the aperture of the lens to regulate the amount or least intensity of light entering the lens, the diaphragm also has an effect in adjusting the focus on the object narrowly or wide. At the time of shooting, the photographer used an aperture of f/6.3 to produce a clear image. As smaller apertures can provide wide focus, the recommended aperture value when shooting interiors is $\mathrm{f} / 4.5-\mathrm{f} / 10$.

b) Shutter Speed: is the speed at which the camera lens sensor opens the lid, when photographing photographers using a shutter speed of 1/20 second, this figure results from a combination of the f/6.3 and Iso 100 diaphragms. Shutter speed is determined from the light triangle setting.

c) ISO: is the light sensitivity present in the camera sensor, when photographing photographers use iso 100 to minimize spots on photos (noise). The recommended iso value for photographing interior space is iso 100-200, to minimize spots on the photo (noise).

d) Focal Lenght: is the distance of the lens to the object, when shooting the photographer positions the lens rotation at $30 \mathrm{~mm}$, as to focus the area on the spot you want to photograph.

\section{CONCLUSION}

The results of experiments from photographing the room (bed) using Mario Wibowo's shooting method based on the results of the interview, it was found that the method is very important to use in making room photography. Important features in room shooting are observation, composition, lighting, equipment preparation, angle-of-view determination and technically maximizing the features of the camera device. The interior room of The House Tour boutique hotel that was used as a sample in this experiment successfully applied Mario Wibowo's photography method. Maximum photographic results have a big impact on the beauty of the photo, affecting the perception of the audience so as to attract the interest of the audience. Photographic results are important for the promotion of hotels or other commercial venues. 


\section{Interior Photograph Experiment of The House Tour Hotel Bandung}

Sandy Dwi Putra \& Kankan Kasmana

\section{REFERENCE}

Andina. Yurista. 2020. Teknik Pencahayaan, dari https://kreativv.com/fotografi/teknikpencahayaan/. Diakses tanggal 14 September 2020.

Ayun, P.Q. 2015. Fenomena Remaja Menggunakan Media Sosial dalam Membentuk Identitas. Program Studi Ilmu Komunikasi, Universitas Ahmad Dahlan, Yogyakarta, Vol. 3, No. 2,

Oktober 2015, hal. $\quad 1-16, \quad$ dari http://journal.uad.ac.id/index.php/CHANNEL/article/download/3270/185. Diakses tanggal 05 September 2020.

Canon Asia. 2018. 6 Cara Menyempurnakan Fotografi Arsitektur Anda dengan Lensa Kit. Dari https://snapshot.canon-asia.com/indonesia/article/id/6-ways-to-perfect-your-architecturalphotography-with-a-kit-lens. Diakses tanggal 13 September 2020.

Fajri, dkk. 2017. Implementasi Desain Visual Media Informasi Digital menggunakan Prinsip Rule of Thirds. Universitas Ibn Khaldun, Bogor,

Vol. 5, No. 2, Oktober 2017, pp. 78-85, hal. 2-3, 2020. Dari http://ejournal.uikabogor.ac.id/krea-tif, Accessed on 05 September 2020.

Foto.co.id. 2020. 11 Teknik Jitu Untuk Menghasilkan Fotografi Arsitektur Yang Keren Dan Menakjubkan | Foto.co.id. dari <https://foto.co.id/11-teknik-jitu-untuk-menghasilkanfotografi-arsitektur-yang-keren-dan-menakjubkan/> [Accessed on 11 September 2020].

Google.com. (2020). Ringkasan Ulasan The House Tour Hotel. dari https://www.google.com/travel/hotels/entity/CgsIjqPIi7SGzv_IARAB/reviews?utm_campaig $\mathrm{n}=$ sharing\&utm_medium=link\&utm_source=htls\&ts=CAESABogCgIaABI. Accessed on 14 September 2020.

Gökdeniz, A. (2018) A New Concept in The Hospitality Industry: Boutique Hotels, Their Features, And Different Implementation Examples. Turkey: Balıkesir University.

Harsanto, P.W. (2020). Retorika Visual Fotografis dalam Iklan Koran. Yogyakarta: PT.Kanisius.

Hicoates. 2020. What's in a Color. < http://hicoates.com/> [accessed on Sepember 11,2020] Copyright (c) 2020 Sandy Dwi Putra, Kankan Kasmana (c) (i) (8) 


\title{
Interior Photograph Experiment of The House Tour Hotel Bandung
}

\author{
Sandy Dwi Putra \& Kankan Kasmana
}

Hyun, M. S. 2016. "Seeing Architectural Photographs: Space and Time in The Works of Julius Shulman and Ezra Stoller”. Dissertation, Doctor of Philosophy, School of Architecture, Georgia Institute of Technology, United States.

K-Shot ${ }^{\mathrm{TM}}$. 2017. 20 Teknik Komposisi Foto untuk Meningkatkan Skill Fotografi K-Shot. dari <https://www.kamerashot.com/belajar-komposisi-foto/> [Accessed on 11 September 2020]. Masterclass . 2020. What Is the Rule of Thirds in Photography? How to Practice the Rule of Thirds and Photography Tips. dari <https://www.masterclass.com/articles/what-is-the-rule-ofthirds-in-photography-how-to-practice-the-rule-of-thirds-and-photographytips\#: :text=How\%20to\%20Practice\%20Photography\%20Using\%20the\%20Rule\%20of,them \%20which\%20ones\%20they\%20like\%20best\%20and\%20why.> [Accessed 14 September 2020].

Narsiskus. Tedy. 2017. Fotografi Arsitektur dan Teknik-Teknik Pencahayaan. Dari https://snapshot.canon-asia.com/indonesia/article/id/architectural-photography-and-lightingtechniques. Accessed on 28 April 2020.

Saint-D. 2019. Pengertian dan Penjelasan Interior Photography. dari <https://www.saintd.co/2019/02/pengertian-dan-penjelasan-interior.html> [Accessed on 11 September 2020].

Siskin, J. (2012) Photographing Architecture. United States: Amherst Media, Inc.

Suharfin. Putriana. 2018. Perkembangan Teknologi dan Dampaknya Bagi Kehidupan Bermasyarakat.

Dari https://www.kompasiana.com/putrianasf/5bd4071512ae94038a6a3839/perkembanganteknologi-dan-dampaknya-bagi-kehidupan-bermasyarakat, Accessed on 11 September 2020. Vanan M. 2016. Fotografi Interior: 5 Kiat Memotret Ruang Komersial. Dari https://snapshot.canon-asia.com/indonesia/article/id/interior-photography-5-tips-on-shootingcommercial-spaces, Accessed on 13 September 2020.

Wahyono. 2016. Memahami Jenis-Jenis Pencahayaan dan Cara Menggunakannya. Dari https://doss.co.id/news/memahami-jenis-jenis-pencahayaan-dan-cara-menggunakannya.

Accessed on 14 September 2020.

Copyright (c) 2020 Sandy Dwi Putra, Kankan Kasmana (c) (7) \& 


\section{Interior Photograph Experiment of The House Tour Hotel Bandung}

Sandy Dwi Putra \& Kankan Kasmana

Wright, Heather. (2011). Boutique Hotel. Hdwright.files.wordpress.com. from

https://hdwright.files.wordpress.com/2011/05/final-programming-book.pdf. diambil 10 September 2020.

Zakia, R. D and Page, D (2011). Photographic Composition a Visual Guide. United States: Elsevier Inc 
Interior Photograph Experiment of The House Tour Hotel Bandung

Sandy Dwi Putra \& Kankan Kasmana

Copyright (c) 2020 Sandy Dwi Putra, Kankan Kasmana

(c) (7) (8) 